\title{
Lymphoproliferative disorders of the orbit: an immunological approach to diagnosis and pathogenesis
}

\author{
A. GARNER, A. H. S. RAHI, AND J. E. WRIGHT \\ From the Department of Pathology, Institute of Ophthalmology, University of London, and \\ Orbital Clinic, Moorfields Eye Hospital, London
}

\begin{abstract}
SUMMARY A prospective immunological study of patients with proptosis due to intraorbital lesions composed largely or exclusively of lymphoid tissue indicates that the use of antisera to specific heavy and light chain antibody components can be helpful in distinguishing between polyclonal and truly neoplastic monoclonal disorders. On the basis of combined histological and immunological information it is possible to delineate 4 categories of patient: those with unequivocal chronic inflammation, those with a virtually pure lymphoproliferative lesion and a polyclonal profile, and those with a monoclonal lymphomatous disorder which may be histologically comparable to the previous category or, in a fourth group, be unmistakably malignant on cytological grounds. The first of these groups will normally respond to corticosteroid treatment, but the others, including the polyclonal lymphoproliferative masses, need radiotherapy. The finding of reduced numbers of circulating $\mathrm{T}$ cells in the presence of low plasma levels of $\operatorname{IgA}$, and of autoantibodies in the serum of a third of the patients, could mean that individuals developing lymphoproliferative lesions in the orbit, whether hyperplastic or neoplastic, are partially immunodeficient.
\end{abstract}

Is it a lymphoma or a pseudotumour? This is the question that has to be faced every time a patient's proptosis is shown to be due to a localised proliferation of lymphocytes. In that a continuous spectrum of histological appearances may be seen from unmistakable chronic inflammation to undoubted malignancy, with many cases falling somewhere between, precise diagnosis can be extremely difficult. Hence the attraction of an additional approach to the differential diagnosis of lymphoproliferative disorders.

The traditional histopathological approach is geared to morphological assessment, but, fortunately, lesions involving lymphocytes also lend themselves to functional evaluation. A hypothesis that is fundamental to distinguishing between hyperplastic (reactive) and neoplastic lymphoid disorders is that a reactive process will cause a number of lymphocytes to respond, whereas a neoplastic lesion stems from a single abnormal cell. Thus both $\mathrm{T}$ and $\mathrm{B}$ lymphocytes can be expected to share in an inflammatory reaction, the latter cells producing a variety of immunoglobulins

Correspondence to Professor A. Garner, Department of Pathology, Institute of Ophthalmology, 17-25 Cayton Street, London EC1V 9AT. which, while having the same antigenic specificity, will probably represent more than one class of immunoglobulin and almost certainly a mixture of kappa and lambda light chains. Conversely, neoplasia is considered to result from the mutation of a single cell so that, should the relevant cell be a B lymphocyte, all the immunoglobulin produced will be of one type with identical light chains.

To determine whether the lymphoproliferative lesions with an overwhelmingly monoclonal profile are truly neoplastic, in that if not already disseminated they do have a potential for metastasis, needs years of careful follow-up, and even then the diagnosis may remain unproved in patients who have received the treatment appropriate to such a presumption. Nevertheless, there are now several studies relating to the orbit and other sites which indicate that it may be practicable to differentiate between neoplastic (monoclonal) and hyperplastic (polyclonal) lymphocytic lesions by immunological methods. ${ }^{1-4}$ In the present paper we describe our interim findings in a long-term study of all patients presenting with suspected lymphoid pseudotumours to the Orbital Clinic of Moorfields Eye Hospital. 
Table 1 Clinical and radiological findings

\begin{tabular}{|c|c|c|c|c|c|}
\hline Case & $\begin{array}{l}\text { Agel } \\
\text { Sex }\end{array}$ & History & Physical signs & Investigations & $\begin{array}{l}\text { Provisional } \\
\text { diagnosis }\end{array}$ \\
\hline 1 & $\begin{array}{l}44 \\
M\end{array}$ & $\begin{array}{l}1 \text { Year painless progressive } \\
\text { left proptosis with diplopia }\end{array}$ & $6 \mathrm{~mm}$ Proptosis & $\begin{array}{l}\text { T3, T4, TRH normal. } \\
\text { CT: enlarged medial and } \\
\text { lateral recti }\end{array}$ & $\begin{array}{l}\text { ? Inflammatory } \\
\text { ? Dysthyroid }\end{array}$ \\
\hline 2 & $\begin{array}{l}71 \\
\mathbf{M}\end{array}$ & $\begin{array}{l}6 \text { Weeks painless swelling } \\
\text { right lower lid }\end{array}$ & $\begin{array}{l}8 \mathrm{~mm} \text { Proptosis, nontender } \\
\text { mass floor of orbit }\end{array}$ & $\mathrm{CT}$ : large mass floor of orbit & Lymphocytic mass \\
\hline 3 & $\begin{array}{l}72 \\
F\end{array}$ & $\begin{array}{l}9 \text { Months progressive } \\
\text { painless left ptosis }\end{array}$ & $\begin{array}{l}\text { Nontender mass upper inner } \\
\text { quadrant }\end{array}$ & Radiographs normal & Lymphocytic mass \\
\hline 4 & $\begin{array}{l}51 \\
\mathbf{M}\end{array}$ & $\begin{array}{l}2 \text { Months painless swelling } \\
\text { right upper eyelid }\end{array}$ & $\begin{array}{l}\text { Nontender mass upper } \\
\text { outer quadrant }\end{array}$ & $\begin{array}{l}\text { CT: large mass extending } \\
\text { posteriorly }\end{array}$ & Lymphocytic mass \\
\hline 5 & $\begin{array}{l}70 \\
F\end{array}$ & $\begin{array}{l}4 \text { Months painless } \\
\text { progressive right proptosis }\end{array}$ & $6 \mathrm{~mm}$ Proptosis & $\begin{array}{l}\text { CT: bilateral orbital } \\
\text { masses, small on left }\end{array}$ & Lymphocytic mass \\
\hline 6 & $\begin{array}{l}34 \\
\mathbf{M}\end{array}$ & $\begin{array}{l}4 \text { Months painful proptosis } \\
\text { with diplopia }\end{array}$ & $4 \mathrm{~mm}$ Proptosis & $\begin{array}{l}\mathrm{CT} \text { : intraconal mass in } \\
\text { contact with globe medially }\end{array}$ & Inflammatory \\
\hline 7 & $\begin{array}{l}14 \\
F\end{array}$ & $\begin{array}{l}3 \text { Months painless swelling } \\
\text { left upper lid }\end{array}$ & $\begin{array}{l}3 \mathrm{~mm} \text { Proptosis, tender } \\
\text { mass superior orbit }\end{array}$ & $\begin{array}{l}\mathrm{CT} \text { : lacrimal gland mass } \\
\text { extending medially }\end{array}$ & Inflammatory \\
\hline 8 & $\begin{array}{l}37 \\
F\end{array}$ & $\begin{array}{l}2 \text { Months left orbital } \\
\text { swelling painful Vth nerve }\end{array}$ & $\begin{array}{l}4 \mathrm{~mm} \text { Proptosis, } \\
\text { 'orbital apex syndrome,' } \\
\text { central scotoma }\end{array}$ & $\begin{array}{l}\text { CT: enlarged lateral rectus, } \\
\text { thickened optic nerve }\end{array}$ & Inflammatory \\
\hline 9 & $\begin{array}{l}80 \\
\mathrm{M}\end{array}$ & $\begin{array}{l}2 \text { Weeks painful swelling } \\
\text { right upper lid }\end{array}$ & $\begin{array}{l}2 \mathrm{~mm} \text { Proptosis, mass } \\
\text { upper outer quadrant }\end{array}$ & CT: mass lacrimal fossa & Inflammatory \\
\hline 10 & $\begin{array}{l}73 \\
F\end{array}$ & $\begin{array}{l}7 \text { Weeks painless swelling } \\
\text { right upper lid }\end{array}$ & Mass upper outer quadrant & Radiographs normal & Lymphocytic mass \\
\hline 11 & $\begin{array}{l}65 \\
F\end{array}$ & $\begin{array}{l}18 \text { Months painless left } \\
\text { proptosis }\end{array}$ & $\begin{array}{l}9 \mathrm{~mm} \text { Proptosis, } \\
\text { subconjunctival } \\
\text { infiltration }\end{array}$ & CT: large diffuse mass & Lymphocytic mass \\
\hline 12 & $\begin{array}{l}57 \\
F\end{array}$ & $\begin{array}{l}3 \text { Years painless swelling } \\
\text { right lower lid }\end{array}$ & Hard mass lower fornix & $\begin{array}{l}\text { CT: small mass anterior } \\
\text { orbital floor }\end{array}$ & Inflammatory. \\
\hline 13 & $\begin{array}{l}75 \\
F\end{array}$ & $\begin{array}{l}6 \text { Months painless swelling } \\
\text { right upper lid }\end{array}$ & Mass upper outer quadrant & $\begin{array}{l}\text { CT: small lacrimal gland } \\
\text { mass }\end{array}$ & Lymphocytic mass \\
\hline 14 & $\begin{array}{l}82 \\
F\end{array}$ & $\begin{array}{l}2 \cdot 5 \text { Years painless } \\
\text { progressive left proptosis }\end{array}$ & $\begin{array}{l}\text { Large mass upper third } \\
\text { orbit }\end{array}$ & Radiographs normal & Lymphocytic mass \\
\hline 15 & $\begin{array}{l}66 \\
F\end{array}$ & $\begin{array}{l}4 \text { Months painless } \\
\text { progressive swelling right } \\
\text { upper lid }\end{array}$ & $\begin{array}{l}5 \mathrm{~mm} \text { proptosis, mass } \\
\text { upper half orbit }\end{array}$ & Radiographs normal & Lymphocytic mass \\
\hline 16 & $\begin{array}{l}52 \\
\mathbf{M}\end{array}$ & $\begin{array}{l}4 \text { Months painless bilateral } \\
\text { swollen lids progressive } \\
\text { proptosis }\end{array}$ & $\begin{array}{l}\text { Bilateral } 9 \mathrm{~mm} \text { proptosis, } \\
\text { diffuse masses each orbit }\end{array}$ & $\begin{array}{l}\text { CT: bilateral diffuse } \\
\text { orbital masses }\end{array}$ & Lymphocytic mass \\
\hline 17 & $\begin{array}{l}54 \\
F\end{array}$ & $\begin{array}{l}4 \text { Months painful swollen } \\
\text { left upper lid }\end{array}$ & $\begin{array}{l}4 \mathrm{~mm} \text { Proptosis mass } \\
\text { upper orbit }\end{array}$ & $\begin{array}{l}\text { CT: mass involving medial } \\
\text { rectus muscle, extending } \\
\text { forward }\end{array}$ & Inflammatory \\
\hline 18 & $\begin{array}{l}57 \\
\mathbf{M}\end{array}$ & $\begin{array}{l}6 \text { Months painless swollen } \\
\text { left upper lid }\end{array}$ & $\begin{array}{l}2 \mathrm{~mm} \text { Proptosis mass upper } \\
\text { inner quadrant }\end{array}$ & $\begin{array}{l}\text { CT: diffuse medial mass in } \\
\text { contact with globe }\end{array}$ & Lymphocytic mass \\
\hline 19 & $\begin{array}{l}63 \\
M\end{array}$ & $\begin{array}{l}3 \text { Months painless mass } \\
\text { left upper lid }\end{array}$ & $\begin{array}{l}2 \mathrm{~mm} \text { Proptosis tender mass } \\
\text { upper inner quadrant }\end{array}$ & $\begin{array}{l}\text { CT: localised mass near } \\
\text { levator }\end{array}$ & Infiammatory \\
\hline
\end{tabular}

\section{Patients and methods}

The 19 patients selected for this study had a demonstrable orbital mass which was thought to be either a lymphoproliferative lesion or an inflammatory pseudotumour after preliminary investigations had excluded other causes (Table 1). All patients had radiographs of the skull, including selective views of the orbits. Computerised tomography (CT) scans in the axial and coronal planes were performed in most cases. Patients were thoroughly examined by a physician to exclude a systemic cause for the orbital mass. This assessment included examination of the peripheral blood.
A provisional diagnosis was made based on the history, physical signs and the results of investigations. Patients with a painful, tender lesion were diagnosed as having an inflammatory pseudotumour, whereas painless nontender masses were thought to be lymphoproliferative lesions, the latter term being used to describe lymphocytic masses which might or might not be neoplastic.

A biopsy was done in all cases. Anterior lesions were approached through the orbital septum or the conjunctiva, more deeply placed lesions through a lateral canthotomy or by disinserting the medial rectus muscle and entering the intraconal space. 


\section{Laboratory investigations}

One part of each tissue sample was fixed in $10 \%$ formol-saline for routine light microscopy of $5 \mu \mathrm{m}$ sections stained by haematoxylin and eosin, methyl green-pyronin $\mathrm{Y}$, and the periodic acid-Schiff sequence. A second piece was fixed in buffered glutaraldehyde for transmission electron microscopy (to be reported separately) and light microscopy using $1 \mu \mathrm{m}$ plastic-embedded sections. The third piece of tissue was used to produce cell monolayers, by pressing the unfixed tissue against a dry slide, and/or frozen sections; subsequently immunofluorescence by a conventional sandwich technique for the presence of IgG, IgM, and IgA antibodies and light chains was performed. Parallel immunohistochemical studies were performed on paraffinembedded sections using a horseradish peroxidase marker. At the time of biopsy blood was collected for immunological study and biochemical assessment of thyroid function (T3, T4, and thyrotropin releasing hormone estimation). The immunological measurements included serum IgG, IgM, and IgA levels by radial immunodiffusion, autoantibodies to nuclear and mitochondrial antigens, smooth muscle, gastric mucosa, and reticulin; $T$ cell proportions as judged by a rosetting technique; and the lymphocyte transformation index in response to nonspecific mitogens (for example, phytohaemagglutinin) and recall antigens, for example, purified protein derivative (tuberculin) stimulation.

\section{Treatment}

Patients with lymphoproliferative lesions were referred to a radiotherapist for evaluation and radiotherapy. A search for systemic involvement was confined to those under 65 years of age or if there was physical evidence of more generalised disease. The amount of radiotherapy administered to the involved area was varied according to the response. The majority were given 25 gray but a total dose as high as 35 gray was needed in some cases ( 1 gray $=100$ rads).

Systemic corticosteroids were given to most of the patients with inflammatory pseudotumours. Some showed evidence of spontaneous resolution or were

Table 2 Immunological and histopathological findings

\begin{tabular}{|c|c|c|c|c|c|c|c|c|}
\hline \multirow[t]{3}{*}{ Case } & \multicolumn{2}{|c|}{ Circulating T cells } & \multirow{2}{*}{\multicolumn{3}{|c|}{$\begin{array}{l}\text { Serum immunoglobulins } \\
(\mathrm{mg} / \mathrm{dl})\end{array}$}} & \multirow{3}{*}{$\begin{array}{l}\text { Auto- } \\
\text { antibodies }\end{array}$} & \multirow{3}{*}{$\begin{array}{l}\text { Tissue } \\
\text { Ig }\end{array}$} & \multirow[t]{3}{*}{ Histopathology } \\
\hline & \multirow{2}{*}{$\begin{array}{l}\text { \% of total } \\
\text { lympho- } \\
\text { cytes }\end{array}$} & \multirow{2}{*}{$\begin{array}{l}\text { Trans. } \\
\text { index }\end{array}$} & & & & & & \\
\hline & & & $\operatorname{Ig} G$ & $\operatorname{Ig} A$ & $\operatorname{Ig} M$ & & & \\
\hline 1 & 68 & & 1240 & 232 & 110 & - & Poly & Chronic inflammation \\
\hline 2 & 67 & & 1670 & 322 & 63 & - & Poly & Indeterminate lymphoproliferative disease \\
\hline 3 & 54 & 76PHA & 822 & 118 & 706 & SMA & Poly & Chronic inflammation \\
\hline 4 & 44 & 5PHA & 1130 & 110 & 178 & - & Mono & Indeterminate lymphoproliferative disease \\
\hline 5 & 82 & 9PHA & 1430 & 250 & 63 & - & Poly & Indeterminate lymphoproliferative disease \\
\hline 6 & 53 & 3PPD & 1230 & 413 & 122 & SMA & Poly & Chronic inflammation with fibrosis \\
\hline 7 & 73 & $\begin{array}{l}\text { 21PHA } \\
\text { 10PPD }\end{array}$ & 1700 & 319 & 112 & - & Poly & Chronic inflammation \\
\hline 8 & 57 & 7PHA & 970 & 82 & 161 & ANA & Poly & Chronic inflammation with fibrosis \\
\hline 9 & 63 & 11PHA & 1560 & 411 & 84 & - & Poly & Chronic inflammation \\
\hline 10 & 60 & & 803 & 279 & 65 & ANA & Mono & Indeterminate lymphoproliferative disease \\
\hline 11 & 65 & 38PHA & 908 & 225 & 159 & - & Mono & Indeterminate lymphoproliferative disease \\
\hline 12 & 60 & 6PHA & 781 & 154 & 64 & - & Poly & Chronic inflammation with fibrosis \\
\hline 13 & 71 & 22PHA & 828 & 181 & 74 & ANA & Mono & Indeterminate lymphoproliferative disease \\
\hline 14 & 62 & 49PHA & 985 & 499 & 109 & SMA & Mono & Indeterminate lymphoproliferative disease \\
\hline 15 & 62 & 35PHA & 1450 & 185 & 233 & AR & Poly & Indeterminate lymphoproliferative disease \\
\hline 16 & 53 & & 471 & 86 & 66 & - & Poly & Indeterminate lymphoproliferative disease \\
\hline 17 & 60 & & 1390 & 482 & 264 & - & Poly & Chronic inflammation (granulomatous) \\
\hline 18 & 45 & & 1030 & 184 & 376 & - & Poly & Indeterminate lymphoproliferative disease \\
\hline 19 & 66 & 8PHA & 845 & 98 & 141 & - & Poly & Chronic inflammation (granulomatous) \\
\hline
\end{tabular}

Chronic inflammation denotes infiltration with lymphocytes and other leucocyte types with or without fibrosis.

Lymphoid hyperplasia indicates an overwhelming predominance of lymphocytes.

Mono=antibody confined to a single type of light chain.

Poly =antibody of more than one sort.

PHA = phytohaemagglutinin.

$\mathrm{PPD}=$ purified protein derivative (tuberculin).

SMA = smooth muscle antibody.

ANA = antinuclear antibody.

AR = antireticulin antibody

SI conversion: immunoglobulins $\mathrm{mg} / \mathrm{dl} \times 0 \cdot 01=\mathrm{g} / \mathrm{l}$. 
minimally inconvenienced and received no treatment. Others were treated with radiotherapy alone. A daily dose of 60-80 mg of prednisolone was given orally for 5-7 days; the dosage was then reduced progressively during the ensuing weeks. If steroids failed to produce complete resolution, or a maintenance dose was needed to control the patient's signs and symptoms, or the use of systemic steroids was judged inadvisable, the lesion was treated with radiotherapy in a manner similar to that employed for lymphoproliferative lesions.

\section{Results}

This interim report deals with some of the immunological aspects of the study and a more complete account covering clinical, therapeutic, immunological, and histopathological parameters will be published later.

The findings in individual cases are given in Tables 2 and 3.
Histology. Two broad categories of cellular infiltration were identified. Nine patients presented lesions in which the lymphocytic population was diffuse and uneven and mainly in the form of small mature lymphocytes. Germinal centres were seen in 2 cases (Fig. 1). Appreciable numbers of other types of leucocyte (chiefly macrophages but also occasional eosinophils and neutrophils) as well as plasma cells were also seen, and the lesions were classified as chronic inflammation. In 3 patients large amounts of fibrous tissue were observed in conjunction with a relatively milder degree of chronic inflammation, and in 2 granuloma formation was seen. The lesion in the remaining 10 patients consisted of marked lymphocytic proliferation (Figs. 2 and 3 ) with small numbers of transformed cells with recognisable but small nucleoli or cleaved nuclei (centrocytes). In a single case (case 19) germinal centre formation was identified, the distribution of immature cells being random in the other 9 patients. Plasma cells were readily identified in 2 cases but were present to some

Table 3 Course of disease and response to treatment

\begin{tabular}{|c|c|c|c|c|}
\hline Case no. & Final diagnosis & Treatment & Response & Follow-up \\
\hline 1 & Chronic inflammation & None & $\begin{array}{l}\text { Gradual resolution of } \\
\text { diplopia }\end{array}$ & 18 Months still proptosis $5 \mathrm{~mm}$ \\
\hline 2 & $\begin{array}{l}\text { Polyclonal lymphoproliferative } \\
\text { lesion }\end{array}$ & $\begin{array}{l}\text { Prednisolone } 40 \mathrm{mg} \text { daily } \\
25 \text { gray }\end{array}$ & $\begin{array}{l}\text { Partial response } \\
\text { Good resolution }\end{array}$ & 18 Months no recurrence \\
\hline 3 & $\begin{array}{l}\text { Polyclonal lymphoproliferative } \\
\text { lesion }\end{array}$ & 25 gray & Resolution & 18 Months no recurrence \\
\hline 4 & $\begin{array}{l}\text { Monoclonal lymphoproliferative } \\
\text { lesion (lymphoma) }\end{array}$ & 30 gray & Resolution & 15 Months no recurrence \\
\hline 5 & $\begin{array}{l}\text { Polyclonal lymphoproliferative } \\
\text { lesion }\end{array}$ & $\begin{array}{l}30 \text { gray (right) } \\
26 \text { gray (left) }\end{array}$ & Resolution & $\begin{array}{l}1 \text { Year mass left orbit required } \\
\text { radiotherapy; } 2 \text { Years no } \\
\text { recurrence }\end{array}$ \\
\hline 6 & Chronic inflammation & $\begin{array}{l}\text { Prednisolone } 80 \mathrm{mg} \\
\text { reducing } 25 \text { gray }\end{array}$ & Resolution above $15 \mathrm{mg}$ & 1 Year no recurrence \\
\hline 7 & Chronic inflammation & $\begin{array}{l}\text { Prednisolone } 60 \mathrm{mg} \\
25 \text { gray }\end{array}$ & $\begin{array}{l}\text { Partial response } \\
\text { Partial response }\end{array}$ & Subsequent right lacrimal gland mass \\
\hline 8 & Chronic inflammation & $\begin{array}{l}\text { Prednisolone } 60 \mathrm{mg} \\
4 \text { days, then reducing to } \\
10 \mathrm{mg} \text { for } 6 \text { months }\end{array}$ & Resolution & 18 Months no recurrence \\
\hline 9 & Chronic inflammation & None & Resolved spontaneously & 18 Months no recurrence \\
\hline 10 & $\begin{array}{l}\text { Monoclonal lymphoproliferative } \\
\text { lesion (lymphoma) }\end{array}$ & 30 gray & Resolution & 18 Months no recurrence \\
\hline 11 & $\begin{array}{l}\text { Monoclonal lymphoproliferative } \\
\text { lesion (lymphoma) }\end{array}$ & 30 gray & Resolution & 18 Months no recurrence \\
\hline 12 & Chronic inflammation & None & Mass remains & 15 Months no change \\
\hline 13 & $\begin{array}{l}\text { Monoclonal lymphoproliferative } \\
\text { lesion (lymphoma) }\end{array}$ & 20 gray & Resolution & 12 Months no recurrence \\
\hline 14 & $\begin{array}{l}\text { Monoclonal lymphoproliferative } \\
\text { lesion (lymphoma) }\end{array}$ & 25 gray & Resolution & 14 Months no recurrence \\
\hline 15 & $\begin{array}{l}\text { Polyclonal lymphoproliferative } \\
\text { lesion }\end{array}$ & 33 gray & Resolution & 13 Months no recurrence \\
\hline 16 & $\begin{array}{l}\text { Polyclonal lymphoproliferative } \\
\text { lesion }\end{array}$ & 20 gray & Resolution & 10 Months no recurrence \\
\hline 17 & Chronic inflammation & 25 gray & Resolution & 10 Months no recurrence \\
\hline 18 & $\begin{array}{l}\text { Polyclonal lymphoproliferative } \\
\text { lesion }\end{array}$ & 25 gray & Resolution & 8 months no recurrence \\
\hline .19 & Chronic inflammation & None & Resolved spontaneously & 2 Years no recurrence \\
\hline
\end{tabular}

Modal dose of $x$-rays in SI units: 1 gray $=100$ rads. 


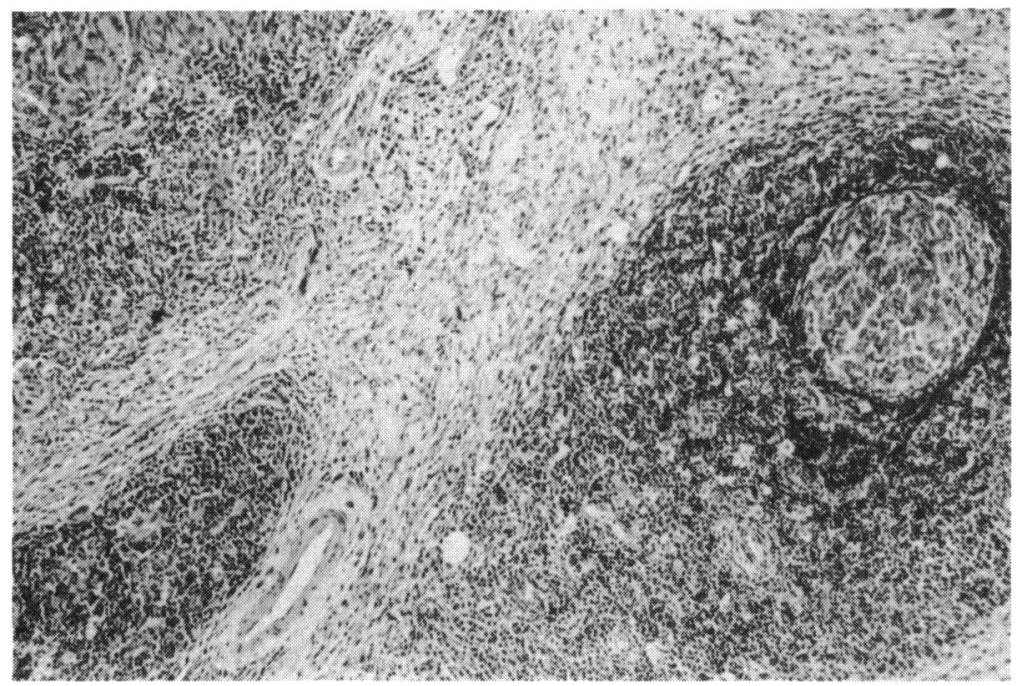

Fig. 1 Chronic orbital inflammation. A granulomatous focus in top left-hand corner is associated with marked lymphocytic infiltration in which germinal centres can be recognised. (Haematoxylin and eosin, $\times 80$ ).

extent in all 10. This latter group were designated as indeterminate lymphoproliferative disease. There were no patients who presented unequivocal histological evidence of (malignant) neoplasia.

Immunology. Immunofluorescence of the monolayer cell impressions and immunoperoxidase

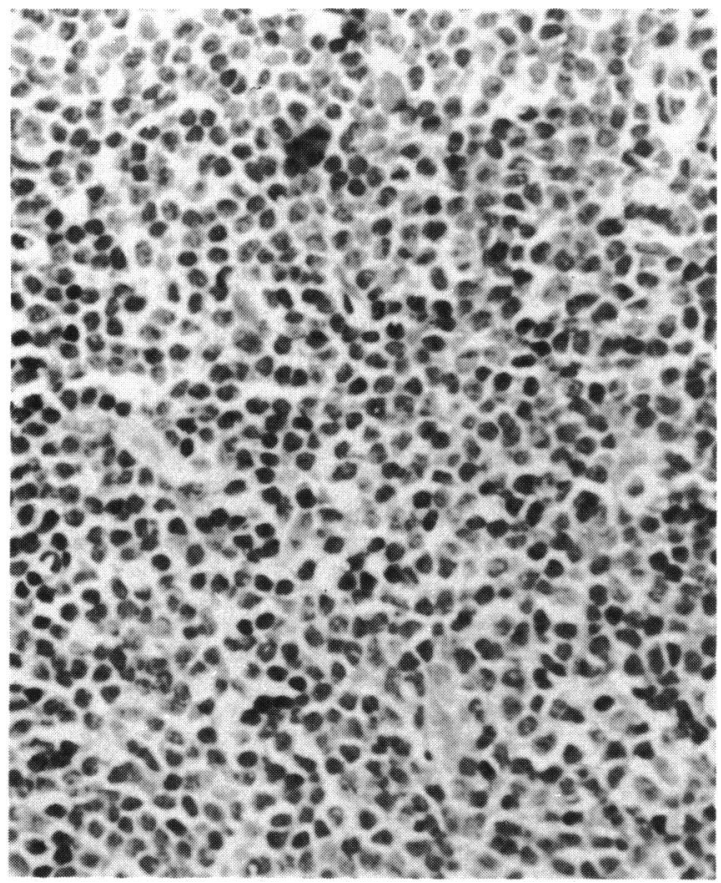

Fig. 2 Polyclonal lymphoproliferative lesion. The cells are mostly small lymphocytes with no cytological irregularity and there are very few nonlymphoid cells. (Haematoxylin and eosin, $\times 430$ ). staining of histological sections showed an unequivocal monoclonal antibody staining pattern in 2 cases (Figs. 4 and 5) and a predominantly monoclonal pattern in another (mainly $\lambda$ light chain immunoglobulins). In each of the remaining 14 cases there was an admixture of $\kappa$ and $\lambda$ light chaincontaining plasma cells and B lymphocytes (Fig. 6), which approximated to the $\kappa: \lambda$ ratio of $2: 1$ pertaining in the circulating blood of the general population.

The IgG levels were not significantly abnormal save in one patient (case 16) in whom there was a general reduction in serum immunoglobulin levels. Five of the 19 patients had serum IgA levels almost 2 standard deviations below the usual mean of 200 $\mathrm{mg} / \mathrm{dl}(2 \mathrm{~g} / \mathrm{l})$ and 4 had serum IgM values that were considerably elevated above the normal mean of 130 $\mathrm{mg} / \mathrm{dl}(1.3 \mathrm{~g} / \mathrm{l})$; in 2 the increase was far beyond 2 standard deviations. Autoantibodies were detected in the serum of 7 patients: in 3 the antibodies were directed against smooth muscle, in 3 they were antinuclear, and in 1 antireticulin.

The proportion of $\mathrm{T}$ cells in the peripheral blood is normally over $65 \%$, but in 6 of the 19 cases it was below $60 \%$. In no case where the capacity for lymphoblastic transformation was tested was there any evidence of functional deficiency in the $T$ cells.

\section{Discussion}

In the absence of long-term follow-up it is impossible to substantiate the accuracy of diagnosis whether clinical, histological, or immunological criteria are used, particularly where the course of the disease has been modified by treatment. Irradiation is an effective treatment for both lymphoma and presumed reactive hyperplasia. ${ }^{5}$ It is probably significant, nevertheless, 


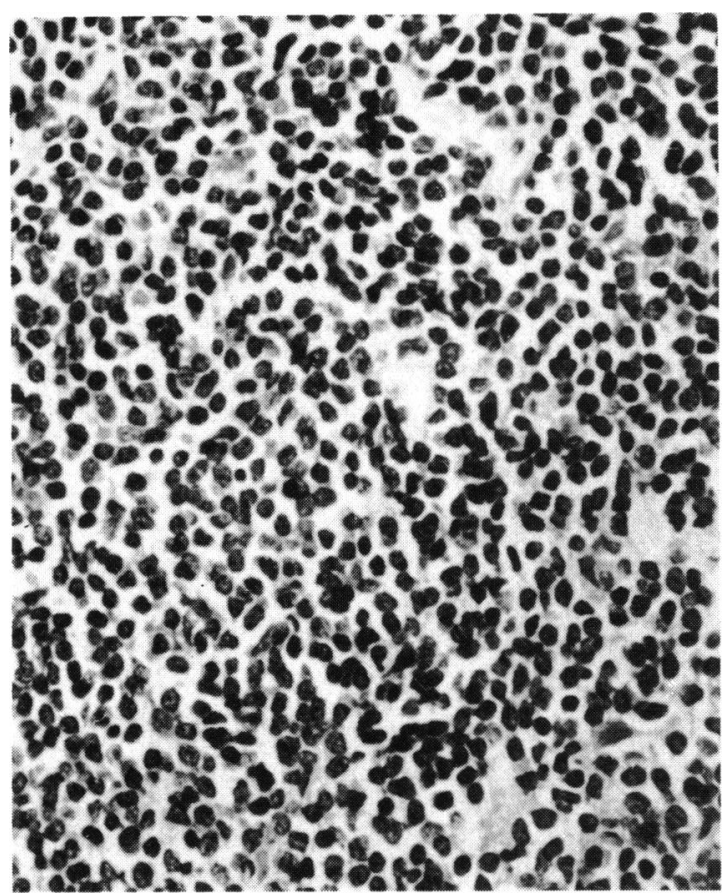

Fig. 3 Monoclonal lymphoproliferative lesions (lymphoma). The uniform mass of predominantly small lymphocytes is histologically indistinguishable from the polyclonal lesion depicted in Fig. 2. In this case, however, there was a monoclonal immunohistochemical profile which together with the bland morphology suggests a lymphoma of low-grade malignancy. (Haematoxylin and eosin, $\times 430$ ).

that of 9 cases diagnosed on histological grounds as likely to have inflammatory disorders none presented a monoclonal immunoglobulin profile in the tissue, whereas of 10 lesions diagnosed as lymphoid hyperplasia 5 were characterised by monoclonal or near monoclonal antibody production. The close correlation of polyclonality with clinical and histological evidence of chronic inflammation, while expected, is reassuring, but it is in the context of the lymphoid hyperplasia group that the chief interest lies. In a detailed morphological study of 22 adnexal lymphoid lesions, most of them involving the orbit, Jakobiec et $a l .^{3}$ found that 5 gave a polyclonal antibody profile and showed no evidence of the systemic involvement that might typify a lymphomatous process in a followup of up to 3 years. The follow-up period in our series is even shorter and does not warrant comparison, but it will be interesting to determine whether the 5 patients coming into this polyclonal lymphoproliferative category continue to be free of disease. For, while monoclonality is the characteristic of malignancy, there is growing evidence that nonmetastasising lymphocytic proliferations in alternative sites to the orbit can be polyclonal. ${ }^{67}$ Furthermore such hyperplastic polyclonal lesions may proceed on occasion to yield a monoclonal lymphoma as a result of subsequent mutation. ${ }^{6}$ The finding that the 3 patients with substantial fibrosis showed a polyclonal antibody picture is in keeping with the view that scar tissue formation is a postinflammatory event.

Jakobiec and his colleagues subdivided their monoclonal lesions on the basis of cytology and found that those characterised by well-differentiated small lymphocytes were free of systemic involvement after brief follow-up, whereas of those showing cytological irregularity slightly more than half presented evidence of disseminated disease. The morphology of the lymphoid infiltrates in the 5 patients in our own series with a monoclonal antibody reaction corresponds to the well-differentiated category and suggests a favourable outcome. Even so it is entirely reasonable to suppose that such 'benign' lymphoproliferative tumours may suffer further mutational events and

Fig. 4 Monoclonal lymphoproliferative lesion (lymphoma). Direct immunofluorescence on a cell impression shows a strong reaction for $\lambda$ light chains on the surface membranes of the proliferating lymphocytes. There was a negative reaction for $x$ light chains. Further immunofluorescence showed a pure IgM synthesis. (The use of monolayer cell impressions gives a much more distinct staining response than can be obtained from frozen sections.) $(\times 800)$.

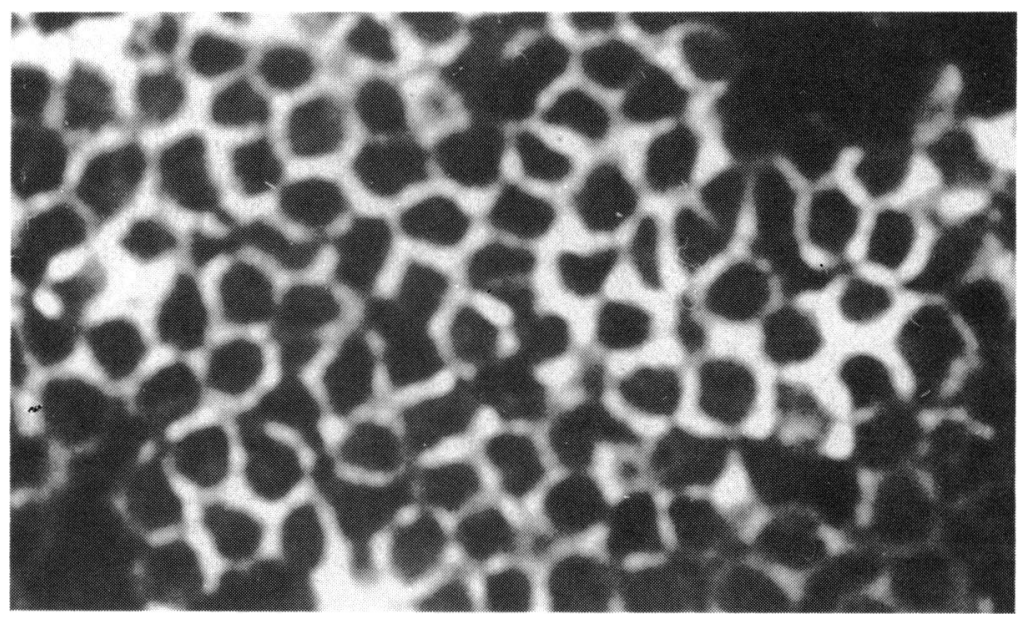




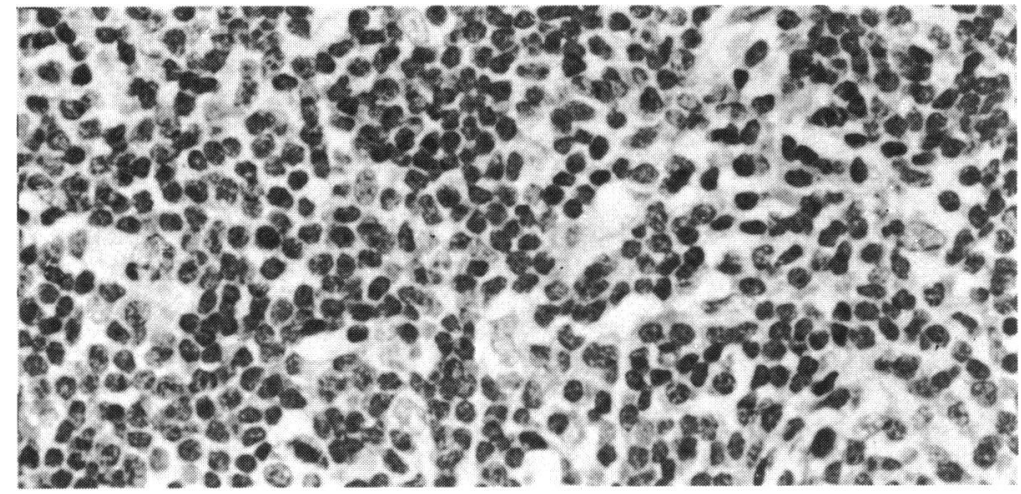

Fig. 5A

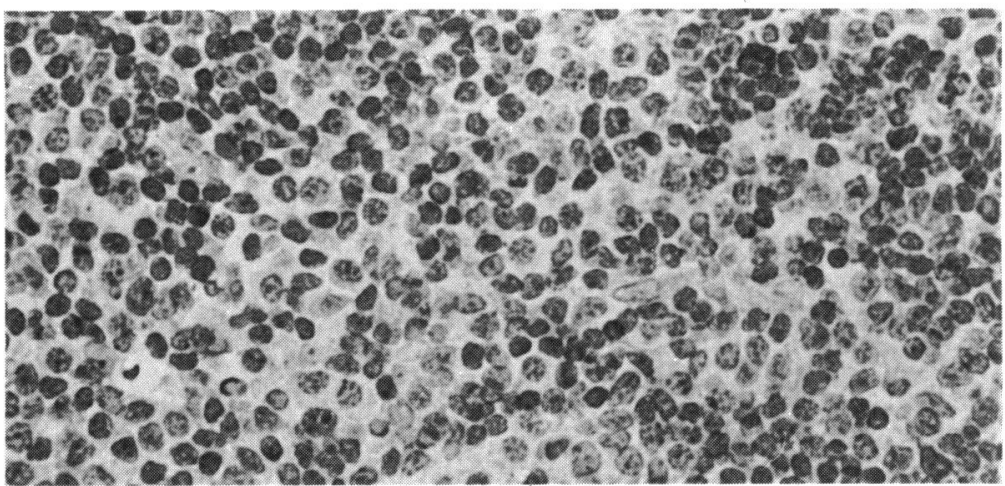

Fig. 5B

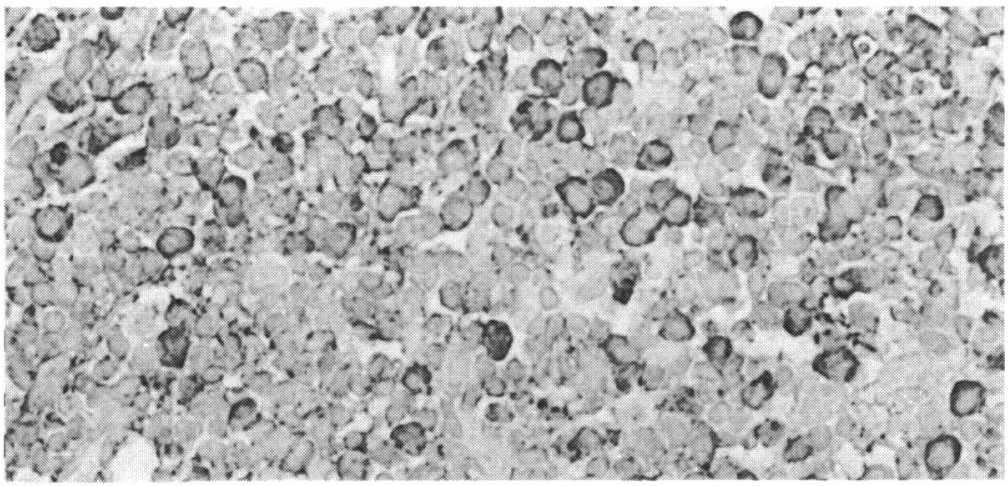

Fig. 5C

develop into metastasising lymphomas. ${ }^{8}$ An increase in immature forms observed in repeat orbital biopsies in patients with lymphocytic proliferations has been reported. ${ }^{9}$ From the standpoint of management it seems appropriate to regard all monoclonal lesions as potential if not actual malignant lymphomas and to treat them accordingly. Indeed, unless the clinical and histological findings indicate an unequivocal in-
Fig. 5 Monoclonal lymphoproliferative lesion (lymphoma). A: Conventional histology shows a proliferation of lymphocytes with scattered immature forms. B: Immunoperoxidase staining for $\kappa$ light chains is negative, but $(\mathrm{C})$ the immunoperoxidase reaction for $\lambda$ light chains has stained the surface of the majority of cells. $(\times 430)$. flammatory process, there is every reason to subject not only the monoclonal lesions but also polyclonal lymphoproliferative disorders to radiotherapy from the outset, the results in the 6 cases so treated in the present study being uniformly satisfactory (Table 3 ).

IgM levels were elevated to above $200 \mathrm{mg} / \mathrm{dl}(2 \mathrm{~g} / \mathrm{l})$ in 4 patients, 2 of whom also had reduced proportions of circulating $\mathrm{T}$ cells. The mean IgM concentration in 
Fig. 6 Polyclonal

lymphoproliferative lesion. A: The histological appearance is of a uniform proliferation of mainly small lymphocytes. The cytoplasm of randomly distributed plasmacytoid cells stained for $(\mathrm{B}) \boldsymbol{\kappa}$ light chains and $(\mathrm{C}) \lambda$ light chains in similar proportions. $(\times 430)$.

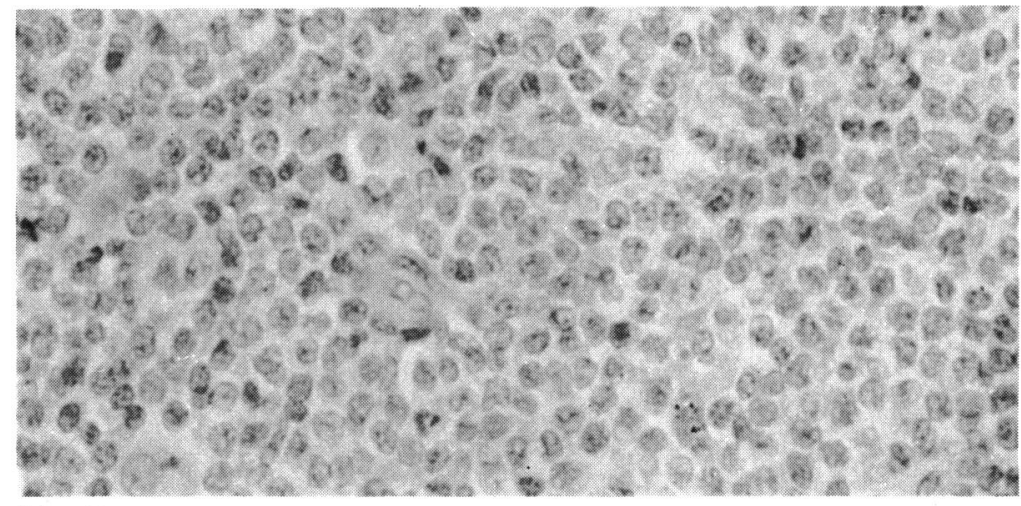

Fig. 6A

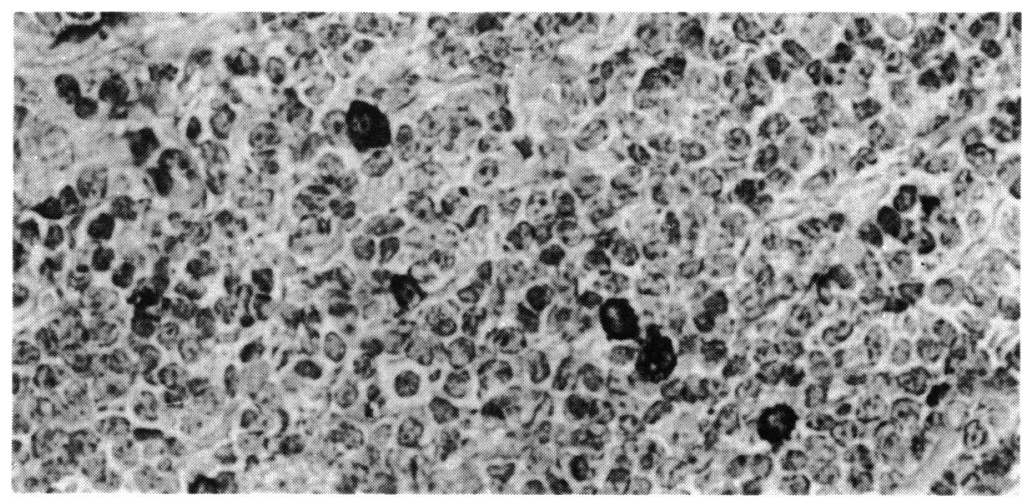

Fig. 6B

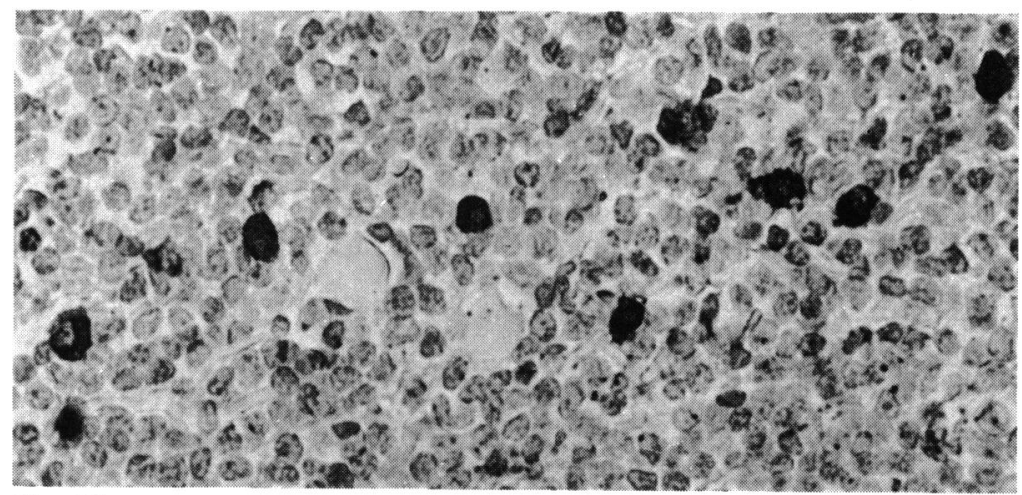

Fig. 6C patients with low T cell counts was $268 \mathrm{mg} / \mathrm{dl}(2 \cdot 7 \mathrm{~g} / \mathrm{l})$, whereas in patients with $\mathrm{T}$ cell counts of $60 \%$ or more the mean IgM level was $119 \mathrm{mg} / \mathrm{dl}(1 \cdot 2 \mathrm{~g} / \mathrm{l})$. This could mean that the reduction in $\mathrm{T}$ cell numbers related principally to the suppressor subset, a deficiency of such cells having a permissive effect on IgM production. Now that specific antisera are available to enable the $T$ cell subsets to be identified, steps to investigate this possibility are being taken and will be reported later.

Apart from one patient with low values for all the immunoglobulin fractions, IgG levels were essentially within normal limits.

However, in contrast to the $\operatorname{IgM}$ levels the $\operatorname{IgA}$ values were reduced in patients with low proportions of circulating $\mathrm{T}$ cells to a mean which was less than 
one-third of that for patients with normal $T$ cell numbers. It is possible that the association is attributable to a deficiency of helper $T$ cell function, and it may be relevant to note that Knowles and Jakobiec $^{10}$ demonstrated just such a reduction in 2 of 6 patients with ocular lymphomas, although this would be to postulate a relative reduction of suppressor activity in respect of one class of antibody (IgM) and of the opposite in respect of IgA. An alternative is that both the $T$ cell and the $\operatorname{IgA}$ deficiencies are separate manifestations of a more widely based inadequacy of immune function.

Autoantibodies were demonstrated in 7 patients, but the only tentative association was with IgA levels, 2 of the 5 such patients having circulating autoantibodies. A correlation between selective IgA deficiency and autoimmune disease has been reported previously, ${ }^{11}$ and it appears that low levels of $\operatorname{IgA}$ carry an increased risk of developing inflammatory disease, autoimmunity, and neoplasia. Selective $\operatorname{IgA}$ deficiency is a fairly common abnormality in the population at large, and in a study of more than 4000 patients with a variety of ocular disorders (mainly inflammatory) Addison and Rahi ${ }^{12}$ found that serum IgA levels below $60 \mathrm{mg} / \mathrm{dl}(0.6 \mathrm{~g} / \mathrm{l})$ occurred in $15 \%$. In the same study $17 \%$ of patients with malignant melanoma of the uvea had low IgA values. It is perhaps worth examining further the possibility that individuals with a reduced output of $\operatorname{IgA}$ and/or low numbers of circulating $T$ cells have an enhanced risk of developing lymphoproliferative disease which may be inflammatory or neoplastic in nature.

Conclusions at this stage in our study must be tentative, but on the basis of the foregoing evidence, both our own and that of other workers, we suggest that 4 broad categories of orbital lymphoid proliferation can be identified:

(1) Unequivocal chronic inflammation. This may or may not be granulomatous but it will show a variety of types of leucocyte and present a polyclonal immunological profile.

(2) Polyclonal lymphoproliferative disease. An almost pure mass of mainly mature lymphocytes is associated with a mixture of antibody types.
(3) Lymphoma (monoclonal lymphoproliferative disease). Histologically similar to the previous category but identified as neoplastic by virtue of a monoclonal antibody profile.

(4) Unequivocal malignant lymphoma. Cytological features of malignancy are allied to monoclonal antibody formation.

We are indebted to $\mathrm{Dr} G$. Lloyd for his radiological analyses, to Dr J. M. Henk for undertaking the radiotherapy, to Mr J. Prasad for performing the immunological tests, to $\mathrm{Mr} \mathbf{R}$. A. Alexander for the histological material, and to Mrs P. Goodwin for typing the manuscript.

\section{References}

1 Knowles DM, Jakobiec FA, Halper JP. Immunologic characterization of ocular adnexal lymphoid neoplasms. Am J Ophthalmol 1979; 87: 603-19.

2 Saraga P, Hurlimann J, Ozzello L. Lymphomas and pseudolymphomas of the alimentary tract: an immunohistochemical study with clinico-pathologic correlations. Hum Pathol 1981; 12: 717-23.

3 Jakobiec FA, Iwamoto T, Knowles DM. Ocular adnexal lymphoid tumors: correlative ultrastructural and immunologic marker studies. Arch Ophthalmol 1982; 100: 84-98.

4 Hautzer NW, Nikolai V. The application of immunoenzymatic techniques to lymphoreticular lesions of the orbit. IRCS Medical Science: The Eye 1982; 10: 229.

5 Orcutt JC, Garner A, Henk JM, Wright JE. Treatment of idiopathic inflammatory orbital pseudotumours by radiotherapy. $\mathrm{BrJ}$ Ophthalmol 1983; 67: 570-74.

6 Banerjee D, Ahmad D. Malignant lymphoma complicating lymphocytic interstitial pneumonia: a monoclonal B-cell neoplasm arising in a polyclonal lymphoproliferative disorder. Hum Pathol 1982; 13: 780-2.

7 Abo W, Takada K, Kamada M, et al. Evolution of infectious mononucleosis into Epstein-Barr virus carrying monoclonal malignant lymphoma. Lancet 1982; i: 1272-6.

8 Freeman C, Berg JW, Cutler SJ. Occurrence and prognosis of extranodal lymphomas. Cancer 1972; 29: 252-6.

9 Chavis RM, Garner A, Wright JE. Inflammatory orbital pseudotumor: a clinicopathologic study. Arch Ophthalmol 1978; 96: 1817-22.

10 Knowles DM, Jakobiec FA. Ocular adnexal neoplasms: clinical, histopathogic, electron microscopic and immunologic characteristics. Hum Pathol 1982; 13: 148-62.

11 Doniach D, Bottazo GF. In: Franklin EC, ed. Clinical immunology update. Amsterdam: Elsevier, North Holland, 1981: 95.

12 Addison DJ, Rahi AHS. Immunoglobulin A (IgA) deficiency and eye disease. Trans Ophthalmol Soc UK 1981; 101: 9-11. 